\title{
CRYPTOGAM RECOLONIZATION AFTER WILDFIRE: LEADERS AND LAGGARDS IN ASSEMBLAGES?
}

\author{
Allan J. Wills", Raymond J. Cranfield, Bruce G. Ward, and Verna L. Tunsell \\ Department of Biodiversity, Conservation and Attractions, Manjimup Research Centre, \\ Locked Bag 2, Manjimup, Western Australia, 6258, Australia \\ *Corresponding author: Tel.: +61-8-9771-7976; e-mail: Allan.Wills@dbca.wa.gov.au \\ ABSTRACT \\ RESUMEN
}

\begin{abstract}
Cryptogams (restricted here to mosses, liverworts, and lichens) have no particular fire-adapted survival strategies and rely on airborne spores or propagules to disperse to new habitats. Following fire, recolonization by cryptogams relies on the propagule sources in regional or local remnant unburned areas and for suitable conditions in the burned area. We used species occurrences on a fire-age (i.e., time since burn) mosaic in jarrah (Eucalyptus marginata Donn ex Sm.) forest near Walpole in southwestern Australia to predict recolonization of cryptogam species in an adjacent forest block. The frequency of a species' occurrence in a fire mosaic predicted the frequency of occurrence in the adjacent forest block that was subjected to an intense wildfire 7.5 years previously. The residuals from a 1:1 prediction were normally distributed when the total lichen and bryophyte flora were considered. Frequencies of species occurrence in the mosaic of fire ages and after recolonization of the wildfire were similar. We interpreted this to indicate that the composition of regional sources of propagules dominated assembly of cryptogam communities after severe fire, rather than community assembly resulting from filtering of species by dispersal ability or

Las criptógamas (restringidas aquí a algunos musgos, hepáticas y líquenes) no tienen estrategias de supervivencia y adaptación al fuego particulares, dependiendo de esporas liberadas en el aire o propágulos para dispersarse en nuevos hábitats. Después de un fuego, la recolonización con criptógamas depende de las fuentes de propágulos en áreas remanentes sin quemar (locales o regionales) y de condiciones favorables en áreas quemadas. Utilizamos la ocurrencia de especies en un mosaico de edades de fuego (i.e., tiempo pasado desde la quema) en bosques de jarrah (Eucalyptus marginata Donn ex Sm.) cerca de Walpole en el sudoeste de Australia, para predecir la recolonización de especies criptógamas en un bloque de bosque adyacente. La frecuencia de la ocurrencia de una especie en un mosaico de fuego predijo la frecuencia de ocurrencia en un bloque adyacente de bosque que fue afectado por un fuego intenso 7,5 años antes. Los residuales de una predicción 1:1 presentaron una distribución normal cuando se consideraron el total de los líquenes y de la flora briófita. Las frecuencias de ocurrencia de especies en el mosaico de edades de fuego y en el de la recolonización después del fuego fueron similares. Interpretamos esto para indicar que la composición de fuentes de propágulos regionales dominaron el ensamble de comunidades de criptógamas luego de fuegos severos, más que el ensamble de comunidades resultantes que dominan por su habilidad de dispersión o de há-
\end{abstract}


habitat suitability. We inferred that ecological requirements favored or disfavored recolonization by some components of the cryptogam flora. The residuals from the predicted frequency of colonizing species of liverworts positively correlated with the number of types of organic substrate they colonized. Lichens and mosses tended to have different preferences for substrates. The fire mosaic and the wildfire block 7.5 years after fire had similar compositions of substrates, so this could not account for differences in species frequency between the fire mosaic and the wildfire block. Differences at phylum level and substrate preferences affect the ability some species to recolonize after fire.

Wildfires have the potential to denude areas of cryptogam species. Regional and landscape-scale mosaics of fire-ages reduce fuel biomass to mitigate intensity and spread of fires while retaining sources of cryptogam propagules and allowing opportunities for recolonization after fires. bitats adecuados. Inferimos que los requerimientos ecológicos favorecen o no la recolonización, basándonos en algunos componentes de la flora criptógama. Los residuales de las especies colonizadoras de hepáticas se correlacionaron positivamente con la cantidad de tipos de sustratos orgánicos que las mismas colonizaron. Los líquenes y musgos tendieron a tener diferentes preferencias para los sustratos. El mosaico de fuego y el bloque de incendios de 7,5 años luego del fuego tuvieron composiciones de sustratos similares, por lo que esto no puede tenerse en cuenta para diferenciar la frecuencia de especies entre el mosaico de fuego y el bloque de incendios. Diferencias a nivel de tipo biológico y preferencias de sustrato afectan la habilidad de algunas especies para recolonizar después del fuego.

Los incendios naturales tienen el potencial de denudar áreas de especies criptógamas. Mosaicos de diferentes edades de incendios a nivel regional y de paisaje reducen la biomasa combustible para mitigar la intensidad y la propagación de fuegos, mientras que retienen fuentes de propágulos de criptógamas y crean oportunidades para su recolonización después del fuego.

Keywords: assemblages, Australia, Eucalyptus marginata, fire-age, lichens, liverworts, mosaic, mosses, recolonization, substrates, time since burn

Citation: Wills, A.J., R.J. Cranfield, B.G. Ward, and V.L. Tunsell. 2018. Cryptogam recolonization after wildfire: leaders and laggards in assemblages? Fire Ecology 14(1): 65-84. doi: 10.4996/fireecology. 140165084

\section{INTRODUCTION}

How a eucalypt forest ecosystem responds to disturbance depends on the fundamental processes of dispersal, colonization, and establishment of biota (Mittelbach and Schemske 2015). A fire has the potential to remove or modify the condition of the habitat and to impact the bryophyte (mosses and liverworts) and lichen flora (collectively termed cryptog- ams) through direct exposure of the organisms to flame and heat. Cryptogams have no particular fire-adapted survival strategies and rely on airborne spores or propagules to disperse to new habitat (e.g., Flø and Hågvar 2013, Nascimbene et al. 2017). The bank of bryophyte diaspores in the soil, originating from fallout or in situ production, represents a source of latent propagules awaiting suitable conditions for germination and growth (Biggs and Wit- 
tkuhn 2006, Iglesias et al. 2015, Glime 2017). Although bryophyte diaspores in the soil may survive fire (Smith et al. 2014), the extent of this strategy in eucalypt forest is unknown. There is some evidence that cryptogam spores and propagules can be carried by animals to habitats preferred by cryptogams (Rudolphi 2009, Zona 2013, Lewis et al. 2014, Barbé et al. 2016a). Cryptogam zoochory in eucalypt forest is largely unknown. Following fire, recolonization by cryptogams relies on regional sources of propagules, and sources in local remnant unburned areas (Hutsemekers et al. 2008; Baker et al. 2013; Gjerde et al. 2015, Barbé et al. 2016b, 2017). There also needs to be suitable conditions in the burned area to allow recolonization (Werth et al. 2006, Smith and Stark 2014, Singh et al. 2015).

The severity of impact and recovery time from fire is linked to fire intensity and scale (Pharo et al. 2013, Barbé et al. 2016b). Low-intensity fires leave unburned patches in which cryptogam species remain present (Hylander and Johnson 2010, Pharo et al. 2013, Barbé et al. 2017). Low-intensity fires potentially provide both unaffected and new habitat in which species that prefer any early to late successional periods are accommodated. Intense fires in eucalypt forests in which the crown is consumed leave burned areas denuded of cryptogam species (Pharo et al. 2013). In that case, the extent to which habitat and dispersal limitation governs recovery of cryptogam assemblages after an intense fire is not clear.

Several mechanisms can lead to differences in colonization rates between species. Cryptogams vary between species in their propensity for sexual versus asexual reproduction and this can affect the potential for long-distance versus short-distance dispersal through the differences in dispersal ability of sexual and asexual or vegetative propagules (Singh et al. 2015, Laenen et al. 2016, Nascimbene et al. 2017). Species-specific characteristics of propagule size and ornamentation are also im- portant modifiers of airborne dispersal ability (Virtanen 2014, Zanatta et al. 2016). While some cryptogams are suited to conditions immediately after fire (Duncan and Dalton 1982, Ryömä and Laaka-Lindberg 2005), suitable conditions for many species are likely to occur only after the vascular flora has at least partially recovered (Turner and Pharo 2005, Turner et al. 2011, Kantvilas and Jarman 2012).

Different species have different responses to post-fire conditions. Patch mosaic burning is postulated to promote biodiversity by providing a range of habitat patches with different fire histories and habitat qualities at a given scale (Parr and Andersen 2006, Burrows 2008, Stein et al. 2014). There is a potential to maximize the geometric mean abundance for the maximum number of species across taxa by selecting an optimal proportion of fire-ages at a landscape scale (Di Stefano et al. 2013), although it is probably difficult for managers of fire to achieve this in a dynamic mosaic. Fireprone landscapes can be considered as dynamic mosaics, at various scales, of more or less temporary refuges that act as sources of propagules and stepping stones for colonizing habitat denuded of species after fires (Robinson et al. 2013). The rate at which species that are vulnerable to fire can move through the dynamic landscape is critical to their survival.

Local abundance of organisms is often highly correlated with regional abundance (e.g., Löbel et al. 2006). The relationship may be causal, in which the abundance of propagules reaching and colonizing a site is related to the abundance of regional propagule sources (Lönnel et al. 2014). The relationship may also depend on local conditions that support particular community compositions as influenced by a hierarchy of regional to local conditions replicated across landscapes (Medina et al. 2014).

In our study, we used least squares regression and species occurrences on a fire-age (i.e., time since burn) mosaic generated in jarrah (Eucalyptus marginata Donn ex Sm.) forest 
near Walpole in southwestern Australia (Burrows and Middleton 2016) to predict recolonization of cryptogam species in an adjacent forest block 7.5 years after a severe and extensive wildfire. Where there are dispersal or habitat filters operating between source populations and recolonization of the burned areas on both forest blocks, we might expect significant kurtosis or skewness in the distribution of residuals arising from the regression using species abundances on the mosaic as the predictor of colonization after the wildfire. This could arise, in part, due to the presence of populations on the mosaic block unaffected by fire and not subject to dispersal and establishment constraints. We tested three hypotheses: (1) that deviation from prediction is related to the number of substrates colonized by a species; (2) that deviation from normality in the relationship between species occurrences on the two forest blocks arises from phylum-level differences in substrate preferences; and (3) that there are different responses to the same substrates at the phylum level.

\section{METHODS}

\section{Study Area}

The study was conducted in London and Surprise forest blocks $30 \mathrm{~km}$ northeast of Walpole in southwestern Australia (Figure 1). The region experiences a mediterranean-type climate with cool wet winters and warm dry summers (Gentilli 1989). Mean annual rainfall is $\sim 1100 \mathrm{~mm}$, most of which falls over the winter months. Mean monthly temperatures range from $15^{\circ} \mathrm{C}$ to $26.7^{\circ} \mathrm{C}$ (Bureau of Meteorology 2016).

The soils and landforms of the study area are derived from granitic gneiss material (Churchward et al. 1988). Landforms are sharply delineated and form catenae of the well-drained ridge and hillslope units (named Collis and Lindesay, respectively) and poorly drained swampy slopes, plains, and drainage floors named Caldyanup (Churchward et al.

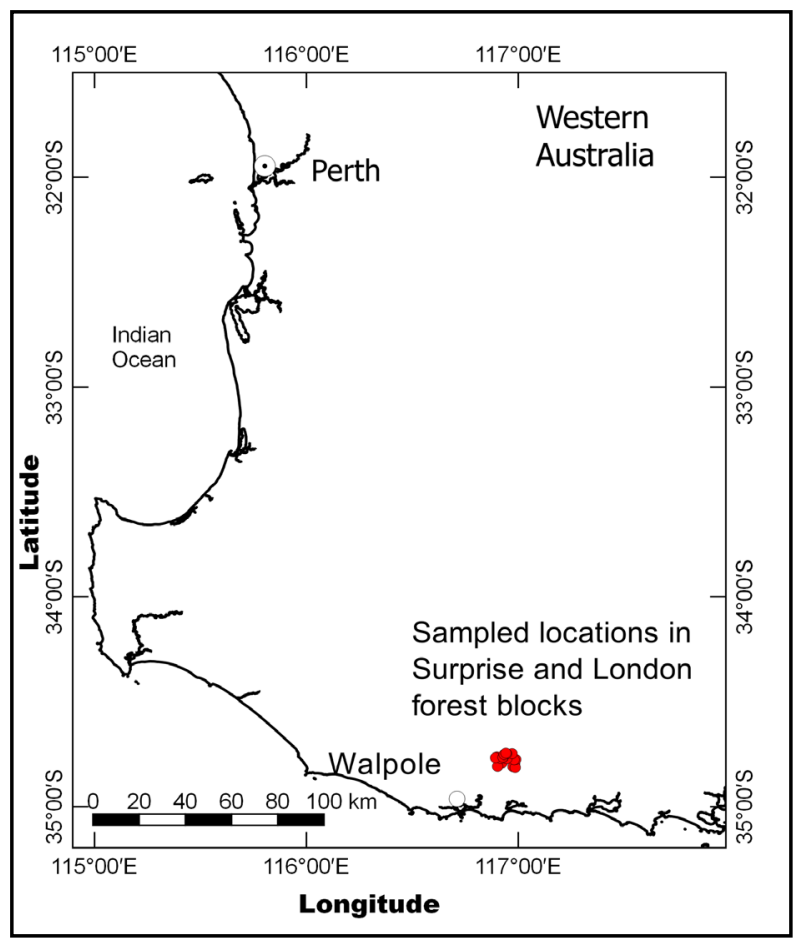

Figure 1. Location of study area at London and Surprise forest blocks, southwest Western Australia.

1988; Mattiske and Havel 1998, 2000; Figure 2). Vegetation on the Collis and Lindesay landform units is mostly comprised of open eucalypt forests to $30 \mathrm{~m}$, dominated by jarrah (Eucalyptus marginata) and marri (Corymbia calophylla [Lindl.] K.D.Hill \& L.A.S. Johnson), with a dense shrubby understory to $2 \mathrm{~m}$ tall. Vegetation associated with the Caldyanup unit is comprised of a variety of reed-dominated seasonal wetlands and heathlands of myrtaceous shrubs to $2 \mathrm{~m}$.

\section{Fire Treatments}

Investigation of cryptogam recolonization after fires was part of a broader fire ecology study (Burrows and Wardell-Johnson 2004, Burrows and Middleton 2016) that opportunistically used the contrasting fire regimes of the adjacent London and Surprise forest blocks. The fire history of the two forest blocks was well understood. Forest blocks of about 5000 ha to 8000 ha are the usual spatial unit of fire management in Western Australian forests. A 


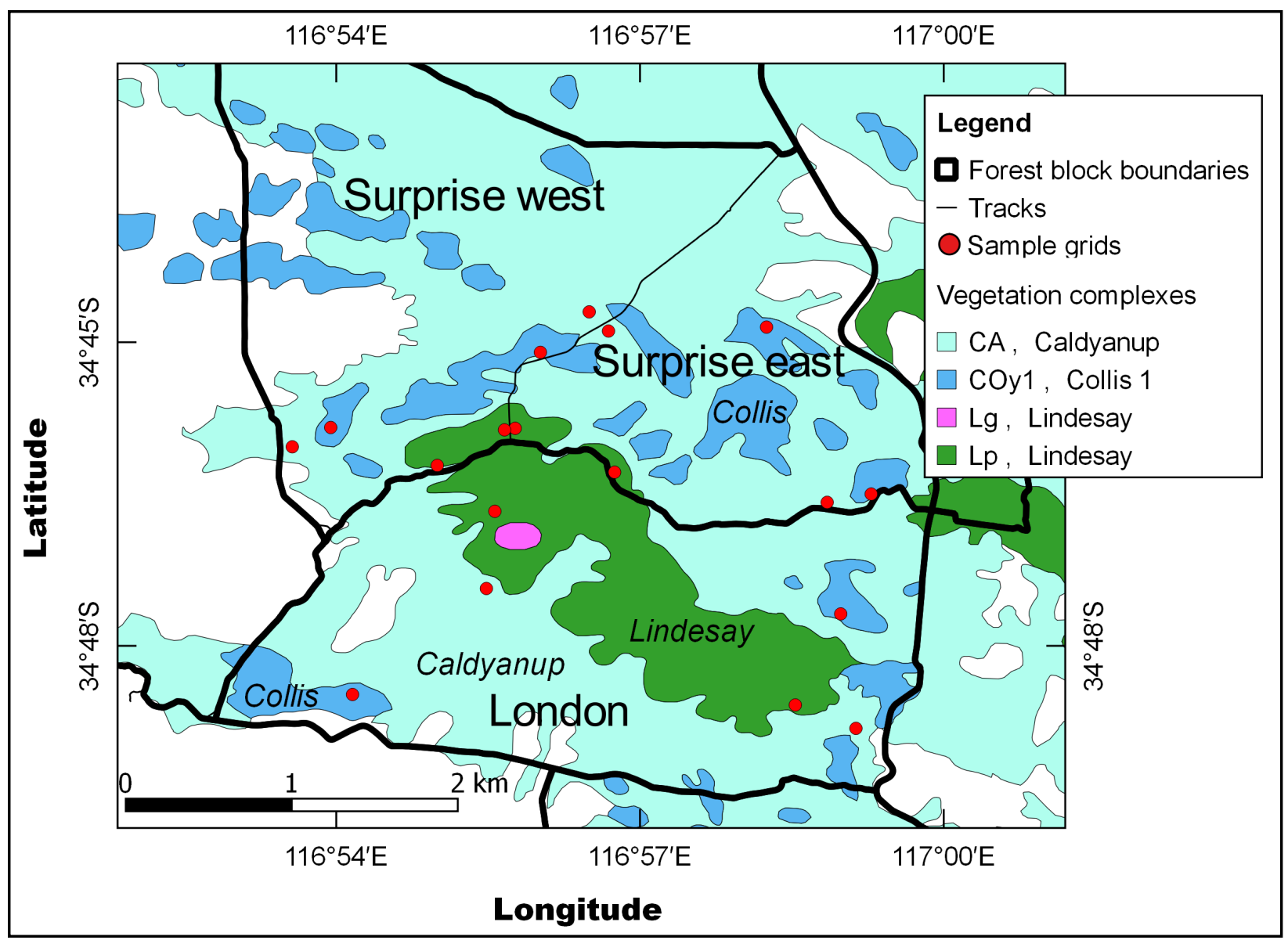

Figure 2. The spatial relationship between Surprise east and Surprise west sub-blocks, and London forest block. White areas are vegetation units not sampled. Names of the particular Caldyanup, Collis and Lindesay vegetation units sampled are specified in the legend according to nomenclature of Mattiske and Havel (1998).

natural wildfire completely burned Surprise forest block ( 6700 ha) in 2003, while London forest block ( $\sim 5000 \mathrm{ha})$ was burned by managed fuel reduction fires in 1994 and 2002. Surprise and London forest blocks differed in their initial and subsequently managed fire regimes. London burned in a managed low-intensity fire in spring 1994, prior to the study. Further prescribed fire was introduced into the London block about every three years over the period 2002 to 2012 in an attempt to create a fine-scale mosaic of patches of vegetation at different ages (seral stages). By 2010, patches of vegetation from a few to several hundred hectares ranged from relatively recently burned to long unburned (Burrows and Middleton 2016). Heterogeneity in fire-ages oc- curred at scales within sample grids (meters to tens of meters) and between sample grids (hundreds of meters to kilometers). Thus, sampling London block in spring 2005 and spring 2010 effectively sampled different fireage mosaic configurations.

Surprise forest block, which adjoins London to the north, burned in a single fire event by an intense wildfire in March 2003 (Witt kuhn and Hamilton 2010). The same fire consumed forest blocks to the west, north, and east. The intensity of the 2003 fire caused spalling of exposed granite and complete combustion of crown foliage. No further fire occurred in Surprise forest block during the measurement period of this study. 
Fires on London block prior to 1994 occurred in spring at intervals of six to nine years (Wittkuhn and Hamilton 2010). Fires on Surprise block previous to 2003 occurred mostly in spring at intervals of six to nine years. Wildfires at an interval of fewer than five years burned two areas of Surprise, affecting only one Lindesay grid prior to the March 2003 fire (Wittkuhn and Hamilton 2010).

\section{Sample Design}

We established 182 ha $(200 \mathrm{~m} \times 100 \mathrm{~m})$ grids for sampling multiple taxa (McCaw et al. 2011 ) in 2005 in the three major land systems described above in both London (6 grids: 3 vegetation units $\times 2$ replicate grids) and Surprise blocks (Figure 2). We divided Surprise block into Surprise east and Surprise west subblocks to accommodate planned fire regimes imposed later than the present study $(2 \times 6$ grids: 2 sub-blocks $\times 3$ vegetation units $\times 2$ replicate grids). The initial placement of grids targeted each of the three main vegetation units (Collis, Lindesay, and Caldyanup) within areas of at least $10 \mathrm{ha}$, and maximum fire-age contrasts within the London forest block. While the vegetation units were not of equal extent in the two forest blocks (Figure 2), each vegetation unit was equally represented in samples from London forest block and Surprise east and Surprise west sub-blocks.

\section{Cryptogam Samples}

Previous experiences of monitoring lichens and bryophytes in jarrah forest (Cranfield et al. 2011) guided the sampling intensity adopted. We established four plots of $50 \mathrm{~m}$ long $\times 2 \mathrm{~m}$ wide $\left(100 \mathrm{~m}^{2}\right), 50 \mathrm{~m}$ apart around the perimeter of the one-hectare central part of the grid (Figure 3). A single assessor (R. Cranfield, Manjimup Research Centre, Western Australia, Australia) noted the presence or absence of each species within each grid in the combined plot area within grids. We reas-

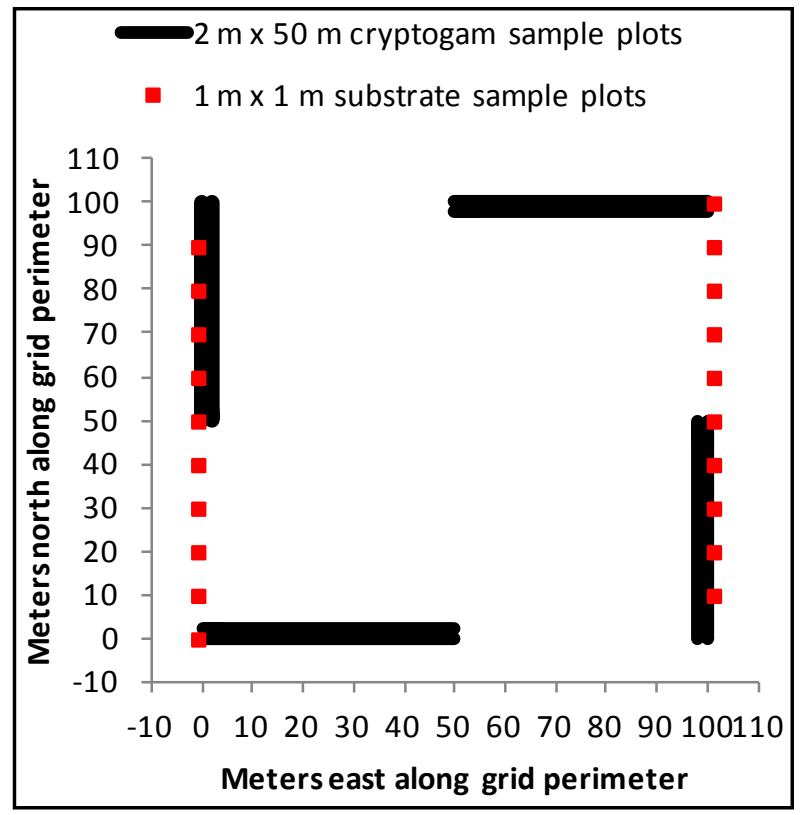

Figure 3. Arrangement of plots within central 1 ha of sample grids. Cryptogams were sampled for presence-absence in the combined area of four $2 \mathrm{~m}$ $\times 50 \mathrm{~m}$ plots on each grid. Substrates were sampled for frequency of $1 \mathrm{~m} \times 1 \mathrm{~m}$ plots on which they occurred out of 20 plots on each grid. Plots were so dispersed to minimize disturbance from concurrent sampling on the grids for other biota.

sessed the same grids in 2010 the same way. New or unknown species were collected for further investigation and identification. A conservative approach to field identification was taken; vouchers were collected and later identified in the laboratory against voucher specimens, specimens held in the Western Australian Herbarium (PERTH in Perth, Australia), and taxonomic literature. Literature consulted for identifying species including the following primary texts: Catcheside (1980), Buck et al. (2002), and McCarthy (2006) for mosses; Scott (1985) and Glenny and Malcolm (2005) for liverworts; and George (1992), Grgurinovic (1994), Lumbsch et al. (2001), McCarthy (2001), McCarthy and Malcolm (2004), McCarthy and Mallett (2004), and McCarthy (2009) for macro-lichens. Vouchers of all collected species were lodged in the Western Australian Herbarium, Perth, Australia. 


\section{Frequency of Substrates}

Twenty plots of $1 \mathrm{~m}^{2}$ were established at intervals of $10 \mathrm{~m}$ along two sides of the central hectare of each grid (Figure 3) in 2010 and the presence or absence of habitat substrates on each plot recorded. We assessed wood (uncharred wood surfaces), bark (uncharred bark surfaces), soil, stone, organic matter (uncharred organic matter other than wood or bark), and charcoal. The frequency of substrates on a sample grid was approximated as the frequency of plots on the grid in which a substrate occurred.

\section{Species Richness}

We tallied the number of species from all grids to derive the total species richness of combined London and Surprise blocks. We tallied the number of species from London and Surprise east and Surprise west sub-blocks separately and for each year to derive the species richness of each forest block or sub-block for each year. We tallied numbers of species within grids, within years, and within forest blocks and calculated average richness per sample grid for each forest block and year.

\section{Analysis}

We calculated the species frequency of occurrence for the London mosaic from 2005 and 2010 data ( 2 years $\times 6$ grids), and for Surprise from 2010 data for only $7.5 \mathrm{yr}$ after fire
(1 year $\times 12$ grids). Assumptions underlying the use of London block as a contributor and predictor are developed below. We assumed a local and regional structure of propagule sources available to the forest blocks at the landscape scale (Table 1). We assumed that the same regional source of propagules was common to both forest blocks. (A common regional source would contribute to a correlation between London and Surprise in the frequency of species occurrences.) Making no assumption of dependence, we tested for correlation in the frequency of species occurrence between London and Surprise blocks. We then assumed that London block was one of, but not the only, source area for propagules for Surprise block. We assumed asymmetry in dispersal between the two forest blocks due to the denudation of Surprise by the wildfire and retention of unburned source areas within London (allowing assumption of the partial dependence of frequency in Surprise on frequency in London with London as a source of propagules for Surprise). Note that propagules from London mosaics in both 2005 and 2010 could contribute to colonization of Surprise by 2010. We used the frequency of occurrence of a species in London in 2005 and 2010 as the predictor of its frequency of occurrence on Surprise east and Surprise west in 2010 in a leastsquares regression. We explored the strength of these assumptions by testing the hypothesis that the regression slope does not differ from zero using an $F$-test of regression coefficients, from the $\mathrm{R}^{2}$ of the actual regression, and test-

Table 1. Summary of assumed sources of cryptogam propagules for London and Surprise forest blocks.

\begin{tabular}{lll}
\hline Propagule source & London, fire-age mosaic & Surprise, recovering from intense fire \\
\hline $\begin{array}{l}\text { Regional source of } \\
\text { airborne propagules }\end{array}$ & $\begin{array}{l}\text { Similar to that of Surprise with a diverse } \\
\text { fire-age composition, and relatively } \\
\text { species rich }\end{array}$ & $\begin{array}{l}\text { Similar to that of London (and including } \\
\text { London) with a diverse fire-age } \\
\text { composition, and relatively species rich }\end{array}$ \\
$\begin{array}{l}\text { Local source of } \\
\text { airborne propagules }\end{array}$ & $\begin{array}{l}\text { London, a diverse fire-age composition, } \\
\text { species rich }\end{array}$ & $\begin{array}{l}\text { Surprise, mainly a single fire-age, species } \\
\text { poor }\end{array}$ \\
Local fire refugia & Many & Few or none \\
Local soil bank & Assumed relatively rich & Assumed depleted by fire \\
\hline
\end{tabular}


ing the slope of the regression against 1:1 prediction using a $t$-test (Zar 1974: 208). We ranked residuals derived from the 1:1 prediction and identified them by taxon to visually present patterns of residual sign and magnitude relating to taxa. We assumed equal dispersal and establishment ability among species and higher taxa and tested this assumption as follows: we generated summary statistics for residuals from the 1:1 prediction including kurtosis and skewness, and performed a Jarque-Bera test for normality in distribution of the residuals from the regression (Jarque and Bera 1987) while interpolating the effects of small sample sizes on the $\chi^{2}$ approximation of $\alpha$ (MathWorks 2017). In addition, local propagule sources were available to London forest block from unburned areas within the mosaic of fire-ages but there were no unburned areas within Surprise block grids. Based on Smith et al. (2014), we assumed that the intensity of the fire on Surprise block depleted the contribution from the local soil bank. Recolonization of soil at an accelerated rate compared to denser inorganic substrates, which might tend to indicate survival of propagules in soil interstices and violation of this assumption, was tested using a Fisher's exact test comparing the proportion present of all species capable of colonizing soil with the proportion present of all species capable of colonizing stone and charcoal substrates $2.5 \mathrm{yr}$ after wildfire.

We performed a PerMANOVA on a resemblance matrix derived from simple matching, with species as samples and the substrates from which they had been collected as variables, to detect systematic differences between bryophytes and lichens in the array of substrates from which they were recovered. Presence-absence in the swamp (Caldyanup) or forest (Collis and Lindesay) vegetation units were also used as variables. The types of substrates considered are the same as those previously mentioned, above. PerMANOVA is analogous to a conventional multivariate analysis of variance (MANOVA), in which each substrate value is treated as an individual attribute of a species, but significance values are determined by randomization. In contrast to conventional MANOVA, the only underlying assumption is that species are interchangeable (i.e., they have the same substrate preferences) if the null hypothesis is true (Anderson et al. 2008). We summarized differences between the bryophytes and lichens visually by using an ordination derived by principal coordinates analysis (PCO; Anderson and Robinson 2003).

To explore which substrates had a greater facility for colonization, we used Welch's $t$-tests to compare average residuals from the 1:1 prediction of species colonizing Caldyanup, forest (Collis or Lindesay), and the above substrates on Surprise block with species not colonizing the substrates or vegetation types.

To examine whether substrate specialization affected colonization ability, we tested for correlation between the number of substrates colonized and deviation from the 1:1 prediction for species of mosses, liverworts, and lichens.

To test whether deviation from normality in the distribution of the residual from the $1: 1$ prediction was characteristic of substrate preference or life form, we classified species as lichens or mosses, as occurring on soil or organic matter (most species occurring on one or the other occurred on both), or only on other substrates (wood, bark, stone, or charcoal). We then generated summary statistics for the categorized residuals from the 1:1 prediction and tested for deviation from normality as above.

\section{RESULTS}

\section{Species Richness}

We recorded a total of 67 species of lichen and bryophytes from all 18 sampling grids within London and Surprise from two sampling years: 40 lichens, 20 mosses, and 7 liverworts. Surprise east and Surprise west subblocks each supported 10 species of lichen 
and bryophytes in 2005, $2.5 \mathrm{yr}$ after the intense bushfire, which was about one-quarter of that observed for London (38 species) in 2005 with a mosaic of mixed fire-ages. In 2010, 35 species were observed in London block while Surprise east and Surprise west sub-blocks supported 29 and 31 species, respectively. Species richness per grid increased in Surprise forest block and, by 2010, 7.5 yr after fire, average species richness per grid was similar between London and Surprise forest blocks (Figure 4).

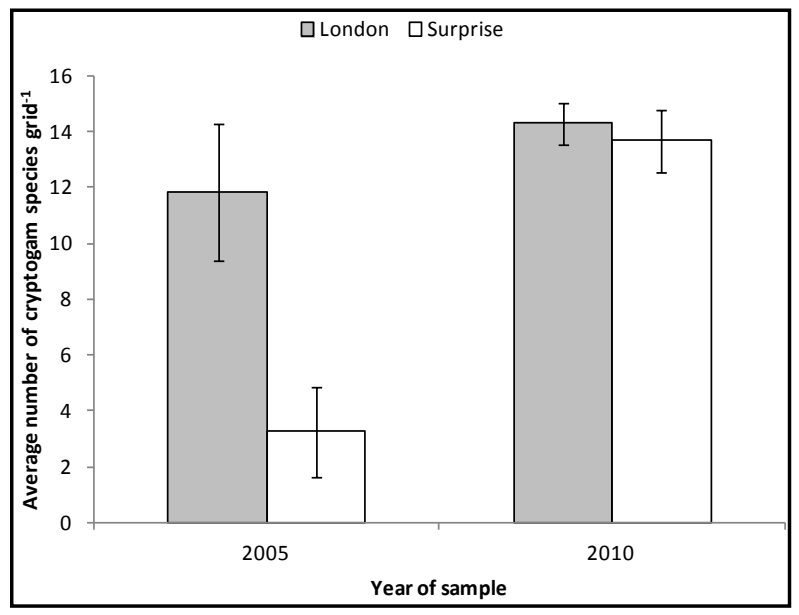

Figure 4. Average number of cryptogam species per sample grid in London (gray bars) and Surprise (white bars) forest blocks for 2005 and 2010 measurements. Fire-ages in London forest block ranged from $3 \mathrm{yr}$ to $\geq 20 \mathrm{yr}$ in 2005 and $2 \mathrm{yr}$ to $\geq$ $25 \mathrm{yr}$ in 2010. Fire-age in Surprise forest block was $2.5 \mathrm{yr}$ in 2005 and $7.5 \mathrm{yr}$ in 2010. Error bars are $\pm \mathrm{SE}$.

Thirty-three percent of the total flora collected was exclusive to London forest block where mixed fire-ages including long unburned substrates were present. Nine percent of the total flora was exclusive to Surprise forest block $7.5 \mathrm{yr}$ after fire, and six percent of the total flora was exclusive to Surprise forest block $2.5 \mathrm{yr}$ after fire (Table 2).

\section{Frequency of Species Occurrence}

We found that, $2.5 \mathrm{yr}$ after fire, the proportion of species present on soils, of all species able to colonize soils, was not significantly different from those able to colonize stone or charcoal, of all species able to colonize stone or charcoal, using a Fisher's exact test. From this, we infer that soil was not more liable than other inorganic substrates to have harbored propagules that survived the intense fire in situ and contributed to recolonization.

The frequency of species occurrences in London and Surprise forest blocks strongly correlated $\left(\mathrm{R}=0.84, P_{(2 \text { tail })} \leq 0.001\right)$. The frequency of species occurrences in London predicted the frequency of species occurrences in Surprise $\left(\mathrm{R}^{2}=0.71, F=155.5, P \leq 0.001\right.$; Figure 5). The slope of the regression $(b=1.158)$ did not significantly differ from the $1: 1$ prediction. The distribution of residuals arising from the 1:1 prediction, when considering all cryptogams, was not significantly different from normal when using the Jarque-Bera test and interpolating the effects of small sample sizes (Table 3). Bryophyte (combined mosses and liverworts) residuals were normally distributed. Moss residuals were non-normal and platykurtic (more species with more variation from predicted frequencies in Surprise forest block than normal expectations). We interpreted this to indicate that dispersal or habitat limitation was more variable between species than expected for mosses. Lichen residuals were non-normally distributed and right skewed (more species with frequencies in Surprise block greater than predicted than normal expectations). We interpreted this to indicate that lichens tended to be slightly better dispersers or that substrates favored lichens more than bryophytes. We did not test for normality in liverwort residuals due to the small sample size. The majority of liverworts appeared less frequently in Surprise than predicted from their frequency in London (Figure 6). The four species with the most negative residuals 
Table 2. The number of occurrences of species exclusive to London or Surprise forest block, or fire-ages. PERTH herbarium specimen numbers are provided for unidentified or un-named material. Fire-ages in London forest block ranged from $2 \mathrm{yr}$ to $\geq 25 \mathrm{yr}$. Fire-age in Surprise forest block was $2.5 \mathrm{yr}$ in 2005 and $7.5 \mathrm{yr}$ in 2010 .

\begin{tabular}{|c|c|c|c|c|}
\hline \multirow[b]{3}{*}{ Species } & \multirow[b]{3}{*}{ Life form } & \multicolumn{3}{|c|}{ Forest block } \\
\hline & & \multirow[t]{2}{*}{ London } & \multicolumn{2}{|c|}{ Surprise } \\
\hline & & & 2005 & 2010 \\
\hline Dicranella dietrichiae (Müll. Hal.) A.Jaeger & Moss & 2 & 0 & 0 \\
\hline Didymodon torquatus (Taylor) Catches. & Moss & 2 & 0 & 0 \\
\hline Pleurophascum occidentale R.E.Wyatt \& A.H.Stoneb. & Moss & 2 & 0 & 0 \\
\hline Buellia dissa (Stirt.) Zahlbr. & Lichen & 2 & 0 & 0 \\
\hline Hypocenomyce scalaris (Ach.) M. Choisy & Lichen & 2 & 0 & 0 \\
\hline Rhizocarpon sp. grey (PERTH 06324452) & Lichen & 2 & 0 & 0 \\
\hline Rosulabryum campylothecium (Taylor) J.R.Spence & Moss & 1 & 0 & 0 \\
\hline Sematophyllum homomallum (Hampe) Broth. & Moss & 1 & 0 & 0 \\
\hline Syntrichia antarctica (Hampe) R.H.Zander & Moss & 1 & 0 & 0 \\
\hline Riccardia crassa (Schwägr.) Carrington \& Pearson & Liverwort & 1 & 0 & 0 \\
\hline Amandinea punctata (Hoffm.) Coppins \& Scheid. & Lichen & 1 & 0 & 0 \\
\hline Calicium abietinum Pers. & Lichen & 1 & 0 & 0 \\
\hline Cladia inflata (F.Wilson) D.J.Galloway & Lichen & 1 & 0 & 0 \\
\hline Cladonia cervicornis var. verticellata (Hoffm.) Ahti. & Lichen & 1 & 0 & 0 \\
\hline Cladonia ochrochlora Flörke & Lichen & 1 & 0 & 0 \\
\hline Cladonia scabriuscula (Delise) Nyl. & Lichen & 1 & 0 & 0 \\
\hline Dictyographa sp. brown lips (PERTH 06322301) & Lichen & 1 & 0 & 0 \\
\hline Diploschistes euganeus (A. Massal.) J.Steiner & Lichen & 1 & 0 & 0 \\
\hline Diploschistes sticticus (Korb.) Müll.Arg. & Lichen & 1 & 0 & 0 \\
\hline Halegrapha mucronata (Stirt.) Lücking & Lichen & 1 & 0 & 0 \\
\hline Hypogymnia pulverata (Nyl.) Elix & Lichen & 1 & 0 & 0 \\
\hline Pannaria elixii P.M. Jørg. \& D.J.Galloway & Lichen & 1 & 0 & 0 \\
\hline Dicranoloma billarderi (Brid.) Paris & Moss & 0 & 1 & 0 \\
\hline Zygodon menziesii (Schwagr.) Arn. & Moss & 0 & 1 & 0 \\
\hline Astrella drummonii (Taylor) R.M.Schust. ex D.G.Long & Liverwort & 0 & 1 & 0 \\
\hline Hypogymnia subphysodes (Kremp.) Filson var. subphysodes & Lichen & 0 & 1 & 0 \\
\hline Triquetrella papillata (Hook.f. \& Wilson) Broth. & Moss & 0 & 0 & 2 \\
\hline Thuidopsis sparsa (Hook.f. \& Wilson) Broth. & Moss & 0 & 0 & 1 \\
\hline Ainoa mooreana (Carroll) Lumbsch \& I. Schmitt & Lichen & 0 & 0 & 1 \\
\hline Caloplaca marina (Wedd.) Zahlbr. & Lichen & 0 & 0 & 1 \\
\hline Cladonia sp. golden coral (PERTH 07320388) & Lichen & 0 & 0 & 1 \\
\hline Tephromela alectoronica Kalb & Lichen & 0 & 0 & 1 \\
\hline Number of species exclusive to forest block and fire-age & & 22 & 4 & 6 \\
\hline Percentage of total species collected & & 33 & 6 & 9 \\
\hline
\end{tabular}

from the 1:1 prediction (less frequent than expected) were the liverworts Lethocolea pansa (Taylor) G.A.M.Scott \& K.G.Beckm., Geobelobryum unguiculatum (Hook.f. \& Taylor) Grolle, Kurzia compacta (Stephani) Grolle, and the lichen Ochrolechia subpallescens
Verseghy. The four species with the most positive residuals from the 1:1 prediction (more frequent than expected) were the three lichens including unidentified "grey green slick" (PERTH 06320082), Thysanothecium scutellatum (Fr.) D.J.Galloway, Diploschistes scrupo- 


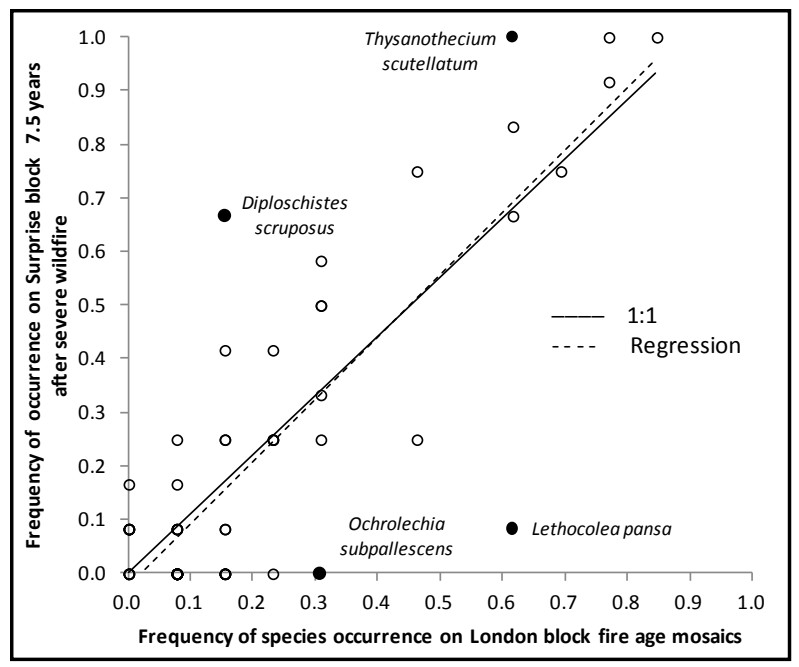

Figure 5. Frequency of grids with cryptogam species occurrence on Surprise forest block $7.5 \mathrm{yr}$ after fire plotted against frequency of grids with species occurrence on London forest block fire-age mosaic. Each data point represents one species; species with the most extreme residual from a 1:1 prediction are labeled. Some data points overlap due to the limited number of grids sampled. For regression: $y=1.158 x-0.023, \mathrm{R}^{2}=0.71$. For test of regression coefficients: $F=155.5, P \leq 0.001$. sus (Schreb.) Norman, and the moss Barbula calycina Schwägr.

From PerMANOVA, lichens were different from both mosses and liverworts in their preferences for substrates (lichens, mosses: $t=$ 2.804, $P_{\text {Perm }}=0.001$; lichens, liverworts: $t=$ 2.231, $\left.P_{\text {Perm }}=0.003\right)$. Mosses and liverworts were not different in their preferences. Preference for soil and organic matter as substrates tended to distinguish between bryophytes and lichens (Figure 7).

London and Surprise forest blocks showed no differences in frequency of respective substrate types. Soil and organic matter were the most common substrates, while stone substrates were least common (Figure 8). Species differed in their ability to colonize depending on the substrate colonized. Species able to colonize Caldyanup grids, stone, or organic material other than wood or bark were more frequent than predicted in Surprise block 7.5 yr after wildfire compared to species not found on these substrates (Table 4).

Table 3. Summary statistics of the distribution of residuals from a 1:1 prediction of frequency of grids in Surprise $7.5 \mathrm{yr}$ after fire carrying a particular species from frequency of grids in London 2005 and 2010 mosaics carrying them. Mean $=$ mean of the residual frequency of grids from the 1:1 prediction. $\mathrm{RMSE}=$ root mean square error, or the standard deviation of residuals from the 1:1 prediction. Jarque-Bera $(J B)$ statistic and probability describe significance of deviation from a normal distribution, ns $=$ not significant.

\begin{tabular}{lcccccc}
\hline Group & Mean & RMSE & Skewness & Kurtosis & JB statistic & $\boldsymbol{P}$ \\
\hline $\begin{array}{l}\text { Cryptogams (lichens, } \\
\text { liverworts, and mosses) }\end{array}$ & 0.008 & 0.16 & 0.17 & 1.95 & 3.43 & $\mathrm{~ns}$ \\
$\begin{array}{l}\text { Bryophytes (liverworts } \\
\text { and mosses) }\end{array}$ & -0.004 & 0.17 & -0.86 & 1.77 & 5.01 & $\mathrm{~ns}$ \\
$\begin{array}{l}\text { Liverworts } \\
\text { Mosses }\end{array}$ & -0.12 & 0.24 & -0.57 & 0.86 & & \\
Lichens & 0.02 & 0.13 & 0.15 & -1.07 & 13.91 & $\leq 0.01$ \\
$\begin{array}{l}\text { Mosses on soil or organic } \\
\text { matter }\end{array}$ & 0.27 & 0.16 & 1.15 & 2.05 & 10.39 & $\leq 0.02$ \\
$\begin{array}{l}\text { Lichens on soil or } \\
\text { organic matter }\end{array}$ & 0.28 & 0.25 & 1.2 & 0.82 & 5.73 & $<0.03$ \\
$\begin{array}{l}\text { Lichens not on soil or } \\
\text { organic matter }\end{array}$ & -0.03 & 0.21 & 1.19 & 2.64 & 5.78 & $<0.03$ \\
\hline
\end{tabular}




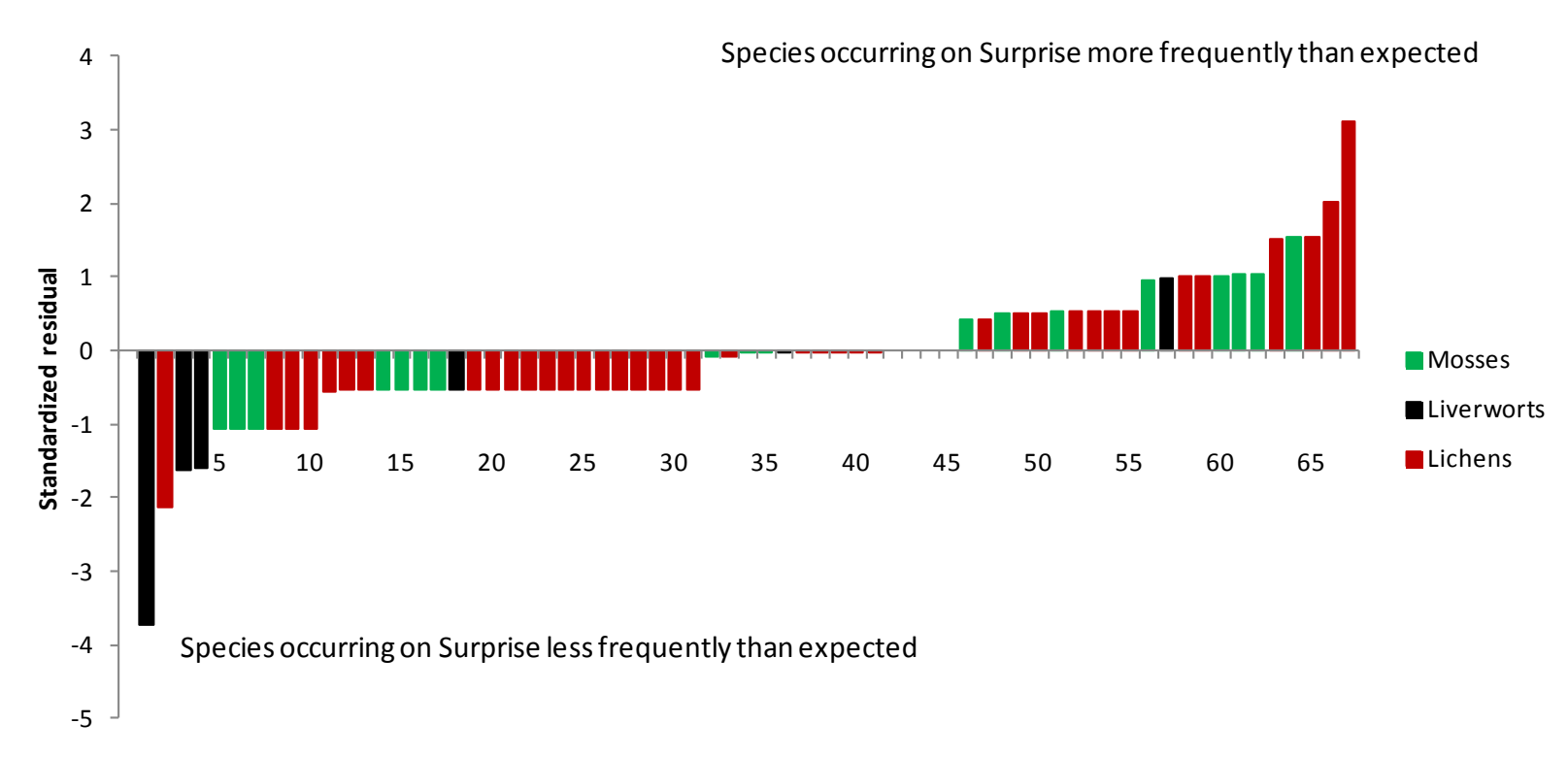

Figure 6. Residuals from the 1:1 prediction of frequency of grids with species occurrence on Surprise forest block using the frequency of grids carrying the species on London forest block fire-age mosaic as a predictor. Residuals are arranged in rank order as indicated on the horizontal axis and identified by taxon with color.

Liverworts, but not mosses or lichens, showed a positive correlation between residuals from the 1:1 prediction from London and the number of types of organic substrates colonized (organic matter, wood, and bark; $P_{(1 \text { tail) }}<$ 0.005). Liverwort residuals were also positively correlated with the total number of types of substrates colonized $\left(P_{(1 \text { tail })}<0.05\right.$; Table 5).

When mosses and lichens were compared with respect to substrate preferences, mosses on soil and organic matter had a platykurtic distribution of residuals, while lichens on the same substrates had a right-skewed and platykurtic distribution of residuals (Table 3). Lichens on bark, wood, stone, or charcoal substrates had a right-skewed and mesokurtic distribution of residuals. Right skewness indicates more positive residuals than normal expectations (dispersal or habitat limitation were weaker than expected and species tended to be better colonists than predicted), and a platykurtic distribution means more species with more variation from normal expectations (dispersal or habitat limitation were more variable than expected and there were more better and worse colonists than predicted). Thus, both phylum level characteristics and species substrate preferences affected colonization ability of some species after wildfire as reflected in the distributions of residuals.

\section{DISCUSSION}

The frequency of occurrence in a fire mosaic predicted the frequency of occurrence in an adjacent forest block $7.5 \mathrm{yr}$ after severe wildfire. In particular, the residuals from the 1:1 prediction considering the total flora were normally distributed. We interpreted this to indicate that, by $7.5 \mathrm{yr}$ after wildfire, the availability of propagules from regional source populations dominated the assembly of cryptogam communities, rather than filtering by dispersal ability or habitat suitability. This concurs with observations on the assembly of bryophyte communities on slag heaps for which both maximum similarity in flora and the highest number of nearest sources of re- 


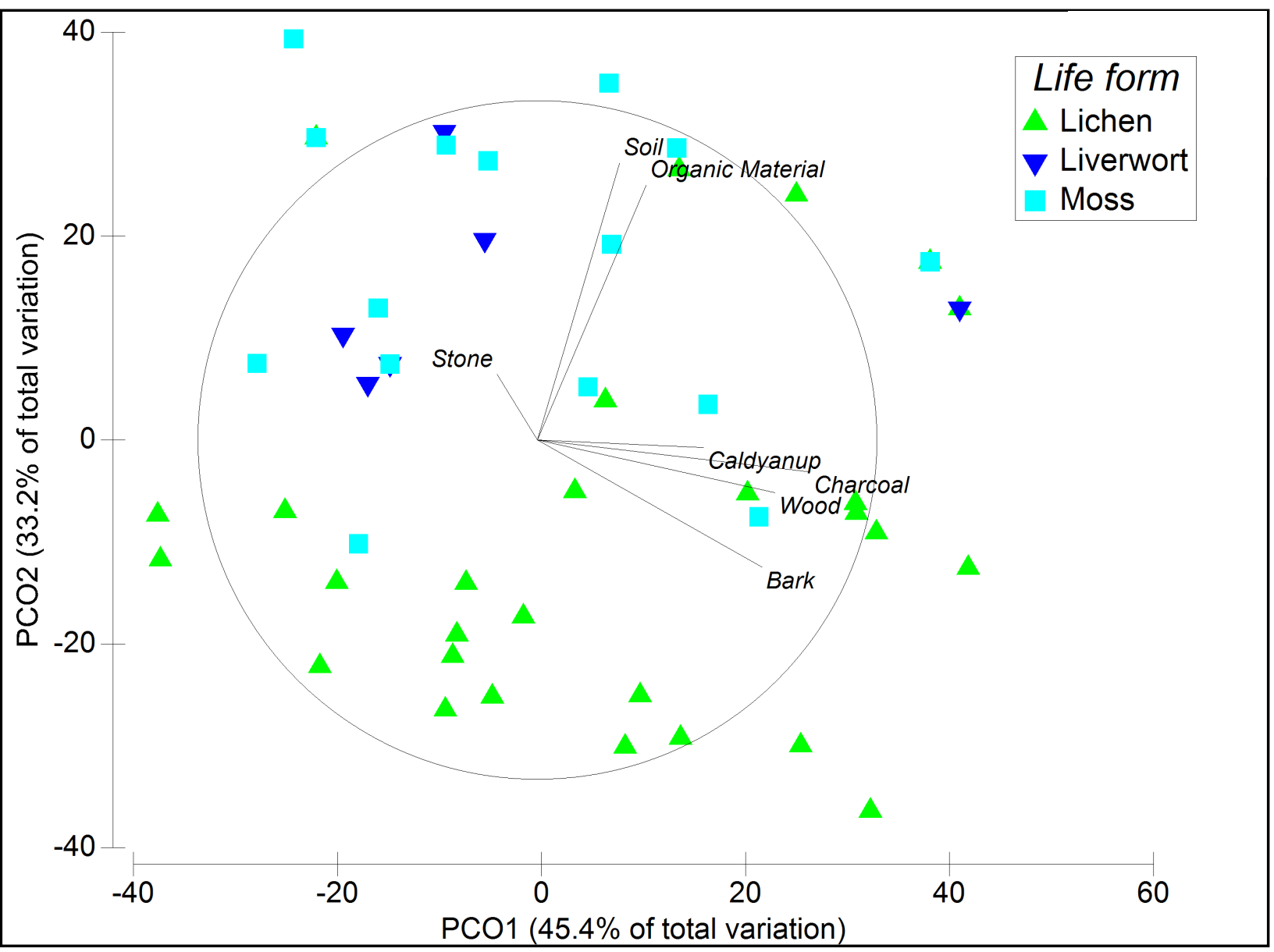

Figure 7. Principal coordinates analysis ordination of a resemblance matrix based on simple matching of cryptogam species according to substrates that they are capable of colonizing and their presence-absence in forest (Collis and Lindesay) and swamp (Caldyanup) vegetation units. Overlying vectors are Spearman correlations of variables with the principal coordinate axes PCO1 and PCO2.

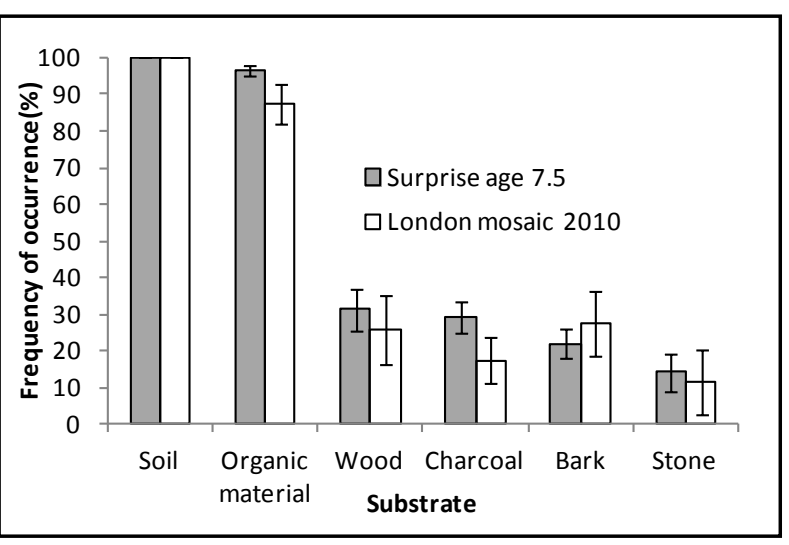

Figure 8. Frequency of encounter of substrates in $1 \mathrm{~m}^{2}$ plots on Surprise 7.5yr after fire and London fire-age mosaic 2010. There are no differences between Surprise and London forest blocks using $t$-tests for each substrate. cruitment were within $10 \mathrm{~km}$ of the sampled site (Hutsemekers et al. 2008). The observations accord with the dominance of long-distance dispersal in the assembly of lichen communities (Gjerde et al. 2015). Our observations also conform to the distance effects on the composition of propagule fallout and establishment in boreal forests after patchy fires (Barbé et al. 2016b).

Exceptions to the regional dominance of assembly occur at phylum and species levels. We inferred that ecological requirements favored or disfavored some components of the cryptogam flora. These exceptions relate to differences in habitat preferences of phyla and species. 
Table 4. Comparison of means of residuals from the 1:1 prediction for species colonizing substrates on Surprise block $7.5 \mathrm{yr}$ after wildfire and species not colonizing those substrates. Probability $\left(P_{(1 \text { tail }}\right)$ of Welch's $t$ statistic ( $t$ stat) generated assuming unequal variances and using the listed degrees of freedom (df). Ability to colonize a substrate is assumed to enhance colonization so 1 tail probability is used. Where $P_{(1-\text { tail) }} \leq 0.05$, mean residual for colonists is $\geq$ mean residual for non-colonists; ns $=$ no significant difference between mean of residuals for colonists and non-colonists. Note that species included are only those for which substrate preferences are known (61 species).

\begin{tabular}{lccccccc}
\hline & $\begin{array}{c}\text { Mean of } \\
\text { residual } \\
\text { frequency } \\
\text { of grids for } \\
\text { non-colonists }\end{array}$ & $\begin{array}{c}\text { Non- } \\
\text { colonists } \\
(\boldsymbol{n})\end{array}$ & $\begin{array}{c}\text { Mean of } \\
\text { residual for } \\
\text { colonists }\end{array}$ & $\begin{array}{c}\text { Colonists } \\
(\boldsymbol{n})\end{array}$ & $\mathbf{d f}$ & $\boldsymbol{t}$ stat & $\boldsymbol{P}_{\mathbf{( 1 \text { tail) }}}$ \\
\hline Caldyanup & -0.215 & 28 & 0.26 & 33 & 49 & -1.94 & 0.03 \\
\hline Collis or Lindesay & -0.130 & 10 & 0.07 & 51 & 41 & -1.03 & $\mathrm{~ns}$ \\
\hline Wood & -0.178 & 28 & 0.22 & 33 & 49 & -1.52 & $\mathrm{~ns}$ \\
\hline Bark & -0.034 & 34 & 0.13 & 27 & 58 & -0.64 & $\mathrm{~ns}$ \\
\hline Organic material & & & & & & & \\
not wood or bark & -0.167 & 31 & 0.25 & 30 & 56 & -1.65 & 0.05 \\
\hline Soil & -0.033 & 37 & 0.15 & 24 & 49 & -0.69 & $\mathrm{~ns}$ \\
Stone & -0.127 & 42 & 0.41 & 19 & 30 & -1.82 & 0.04 \\
\hline Charcoal & -0.010 & 35 & 0.11 & 26 & 54 & -0.44 & $\mathrm{~ns}$ \\
\hline
\end{tabular}

Table 5. The correlation between the numbers of substrates colonized by species of a taxon and the residuals from a 1:1 prediction of their frequency in Surprise age $7.5 \mathrm{yr}$ from frequency in London 2005 and 2010. Cell values are correlation coefficient R. Significant correlations are followed by level of significance (1 tail, positive correlations expected). Organic substrates are wood, bark, and organic matter other than wood or bark. Mineral substrates are stone, soil, and charcoal.

\begin{tabular}{lccc}
\hline & \multicolumn{3}{c}{ Correlation with number of substrates colonized } \\
\cline { 2 - 4 } Life form & Organic & $\begin{array}{c}\text { Mineral } \\
\text { (including charcoal) }\end{array}$ & Total \\
\hline Moss & 0.18 & 0.17 & 0.22 \\
Liverwort & $0.90, P<0.005$ & 0.34 & $0.74, P<0.05$ \\
Lichen & 0.11 & 0.13 & 0.14 \\
\hline
\end{tabular}

For liverwort species, but not lichens or mosses, deviation from predicted frequencies correlated with the number of types of organic substrates colonized. Habitat specialization affected colonization ability for liverworts. Species colonizing the most organic substrate types were more frequent than predicted, while species colonizing no or few organic substrates were less frequent than expected. While the presence of too few liverworts prevented meaningful tests for normality in residuals, we documented lower than expected liverwort species frequencies in Surprise forest block.

Elsewhere, geographical range sizes in liverworts show differences according to whether or not vegetative propagules are produced, indicating that lack of vegetative reproduction limits dispersal ability particularly for 
long-distance dispersal (Laenen et al. 2016). On the other hand, liverworts require moist habitat and removal of biomass cover by fire results in greater exposure of habitat. Liverworts appear to be particularly sensitive to disturbance by fire in both boreal (Paquette et al. 2016, Barbé et al. 2017) and wet eucalypt forest (Kantvilas et al. 2015). Liverworts are abundant in wet eucalypt forest where fires are infrequent and recover greatest species richness in these forests decades after disturbance by silviculture or fire (Turner et al. 2011). Later seral stages of wet eucalypt forests would have the greatest diversity of organic substrates for liverworts and tend to accommodate substrate specialization.

We found lichens and mosses contravened normality in the distribution of residuals. That is, variations from predictions are expected for cryptogams, yet the variations observed were exceptional for lichens and mosses. Lichens tended to be right skewed in their distribution of residuals. More lichen species were more frequent colonists than expected. Mosses had a platykurtic distribution of residuals. More moss species were more or less frequent colonists than expected. We interpreted this to indicate weaker than expected dispersal or habitat limitations in lichens, and more variable than expected dispersal or habitat limitations in mosses.

London and Surprise forest blocks had similar frequencies of available substrates on the sample grids, so this is not a mechanism accounting for differences between phyla in colonization of Surprise forest block. Species able to colonize Caldyanup vegetation units, stone, or organic substrates had a greater propensity for colonization than species not colonizing these substrates. Mosses and lichens showed differences in preferred substrates, and we suggest that these differences in substrate preferences resulted in differences in the distribution of residuals according to both substrate and phylum. Habitat limitation differs between phyla because of differences in spe- cies-level tendencies for substrate preference between phyla, and some substrates are more readily colonized than others ( $c f$. Kumar et al. 2017).

Assembly of lichen floras on forelands of retreating glaciers was affected by dispersal ability and ecological characteristics of lichen species (Nascimbene et al. 2017). Similar mechanisms differentiating recolonization ability might operate for some species in lichen recolonization after an intense fire. The presence of habitat preferences among mosses is well known from bryophyte succession after disturbance (e.g., Duncan and Dalton 1982, Esposito et al. 1999, Kantvilas and Jarman 2012). This leads to differences in the composition of established flora from source and propagule fallout compositions (Barbé et al. $2016 b$ ) as habitats change with the progression of seral stages.

A third of all species collected in our study remained absent from Surprise block $7.5 \mathrm{yr}$ after severe fire. Cryptogam species differ in their relative ability to disperse and establish after fire. Some species and taxa are leaders in dispersing and establishing (Jackson 1971, Esposito et al. 1999, Ryömä and Laaka-Lindberg 2005, Kantvilas and Jarman 2012), while others are laggards (Turner et al. 2011, Paquette et al. 2016), or transiently present (Turner et al. 2011, Kantvilas and Jarman 2012). Retaining unburned patches that serve as source populations of laggards and regionally rare species is vital. Distributions of slowly dispersing cryptogams in contemporary landscapes may reflect historic linkages to source populations of propagules rather than contemporary linkages, thereby concealing an extinction debt in which the rate of landscape-change (in this case, governed by fire return intervals) exceeds dispersal capabilities (Johansson et al. 2013). Long undisturbed patches that accumulate uncommon species and those with specialized habitat requirements provide a "storage" effect (Roxburgh et al. 2004), enabling the regional persistence of those components of the flora 
(Fenton and Bergeron 2008). We suggest that some species, being more scarce than expected in the early recolonization of Surprise forest block, demonstrates the benefits of fire-age mosaics including long-unburned patches and diverse seral stages in providing and maintaining a regional source of propagules ( $c f$. Barbé et al. 2017).

The potential for severe and extensive fires is likely to increase in the southwestern Australian forested landscape in response to a drying and warming climate trend, and a growing urban and wildland interface where human-caused ignitions become increasingly likely (Enright and Fontaine 2014). Meta-population dynamics demonstrated for fauna after a recent extensive and severe fire in moist karri and jarrah forest in southwestern Australia (Bain et al. 2016) provide an indicator that some elements of cryptogam floras are also likely to have suffered long-term depletion in those forests. Managed reintroduction of fire to reduce fuel loads in landscapes subject to previous intense fires depends on a comprehensive disposition of sources of cryptogam propagules to promote their retention in fire-age mosaics that include long-unburned patches.

\section{ACKNOWLEDGEMENTS}

We thank J. Farr, I. Abbott, and N. Burrows for critical comments on an earlier draft of the manuscript, and M. Williams for advice on the Jarque-Bera statistical test. We thank two anonymous reviewers who provided encouragement, careful readings, and insightful criticism of an earlier draft of the manuscript.

\section{LITERATURE CITED}

Anderson, M.J., and J. Robinson. 2003. Generalised discriminant analysis based on distances. Australian \& New Zealand Journal of Statistics 45(3): 301-318. doi: 10.1111/1467-842X. 00285

Anderson, M, R.N. Gorley, and R.K. Clarke. 2008. PERMANOVA+ for PRIMER: guide to software and statistical methods. PRIMER-E, Plymouth, England, United Kingdom.

Bain, K., M. Halley, B. Barton, A. Wayne, A. McGilvray, I. Wilson, and J. Wayne. 2016. Survival of quokkas in the 2015 Northcliffe bush fire: understanding the impact of intense and broadscale fire on an important population of quokkas in the southern forest of Western Australia. WWF-Australia, Wembley, Australia.

Baker, T.P., G.J. Jordan, P.J. Dalton, and S.C. Baker. 2013. Impact of distance to mature forest on the recolonization of bryophytes in regenerating Tasmanian wet eucalypt forest. Australian Journal of Botany 61: 633-642. doi: 10.1071/BT13250

Barbé, M., É.E. Chavel, N.J. Fenton, L. Imbeau, M.J. Mazerolle, P. Drapeau, and Y. Bergeron. 2016. Dispersal of bryophytes and ferns is facilitated by small mammals in the boreal forest. Écoscience 23: 67-76. doi: 10.1080/11956860.2016.1235917

Barbé, M., N.J. Fenton, and Y. Bergeron. 2016. So close and yet so far away: long-distance dispersal events govern bryophyte metacommunity reassembly. Journal of Ecology 104(6): 1707-1719. doi: 10.1111/1365-2745.12637

Barbé, M., N.J. Fenton, and Y. Bergeron. 2017. Are post-fire residual forest patches refugia for boreal bryophyte species? Implications for ecosystem based management and conservation. Biodiversity and Conservation 26: 943-965. doi: 10.1007/s10531-016-1281-9

Biggs, L., and R.S. Wittkuhn. 2006. Bryophyte diaspore banks in soil and litter of an urban bushland in Perth, Western Australia. Hikobia 14(4): 375-382. 
Buck, W.R., D.H. Vitt, and W.M. Malcolm. 2002. Key to the genera of Australian mosses. Australian Biological Resources Survey, Canberra, Australian Capital Territory, Australia.

Bureau of Meteorology. 2016. Weather data online. <http://www.bom.gov.au/>. Accessed 12 February 2016.

Burrows, N. 2008. Linking fire ecology and fire management in south-west Australian forest landscapes. Forest Ecology and Management 255: 2394-2406. doi: 10.1016/j.foreco. 2008.01.009

Burrows, N., and T. Middleton. 2016. Mechanisms enabling a fire sensitive plant to survive frequent fires in south-west Australian eucalypt forests. Fire Ecology 12(1): 26-39. doi: 10.4996/fireecology. 1201026

Burrows, N.D., and G. Wardell-Johnson. 2004. Implementing fire mosaics to promote biodiversity and prevent severe wildfires in south-west Australian ecosystems. Department of Conservation and Land Management, Kensington, Western Australia, Australia.

Catcheside, D.G. 1980. Mosses of South Australia. South Australian Government, Adelaide, Australia.

Churchward, H.M., W.M. McArthur, P.L. Sewell, and G.A. Bartle. 1988. Landforms and soils of the south coast and hinterland W.A. Northcliffe to Many Peaks. CSIRO Water Resources Divisional Report 88/1. CSIRO Publishing, Canberra, Australian Capital Territory, Australia.

Cranfield, R.J., R.M. Robinson, M.R. Williams, and V.L. Tunsell. 2011. Forestcheck: the response of lichens and bryophytes to silviculture in jarrah (Eucalypt marginata) forest. Australian Forestry 74(4): 303-314. doi: 10.1080/00049158.2011.10676374

Di Stefano, J., M.A. McCarthy, A. York, T.J. Duff, J. Slingo, and F. Christie. 2013. Defining vegetation age class distributions for multispecies conservation in fire-prone landscapes. Biological Conservation 166: 111-117. doi: 10.1016/j.biocon.2013.06.022

Duncan, D., and P.L. Dalton. 1982. Recolonisation by bryophytes following fire. Journal of Bryology 12: 53-63. doi: 10.1179/jbr.1982.12.1.53

Enright, N.J., and J.B. Fontaine. 2014. Climate change and the management of fire-prone vegetation in southwest and southeast Australia. Geographical Research 52(1): 34-44. doi: 10.1111/1745-5871.12026

Esposito, A., S. Mazzoleni, and S. Strumia. 1999. Post-fire bryophyte dynamics in Mediterranean vegetation. Journal of Vegetation Science 10: 261-268. doi: 10.2307/3237147

Fenton, N.J., and Y. Bergeron. 2008. Does time or habitat make old-growth forests species rich? Bryophyte richness in boreal Picea mariana forests. Biological Conservation 141(5): 13891399. doi: 10.1016/j.biocon.2008.03.019

Flø, D., and S. Hågvar. 2013. Aerial dispersal of invertebrates and mosses close to a receding alpine glacier in southern Norway. Arctic, Antarctic and Alpine Research 45(4): 481-490. doi: 10.1657/1938-4246-45.4.481

Gentilli, J. 1979. Climate of the jarrah forest. Pages 23-40 in: B. Dell, J.J. Havel, and N. Malajczuk, editors. The jarrah forest-a complex Mediterranean ecosystem. Kluwer Academic Publishers, Dordrecht, The Netherlands.

George, A.S. 1992. Flora of Australia: volume 54, lichens-introduction, Lecanorales 1. Australian Government Publishing Service Canberra, Australian Capital Territory, Australia.

Gjerde, I., H.H. Blom, E. Heegaard, and M. Sætersdal. 2015. Lichen colonization patterns show minor effects of dispersal distance at landscape scale. Ecography 38(9): 939-948. doi: 10.1111/ecog.01047 
Glenny, D., and B. Malcolm. 2005. Key to Australasian liverwort \& hornwort genera. Australian Biological Resources Study, Canberra, Australian Capital Territory, Australia; Centre for Biological Information Technology, Brisbane, Queensland, Australia.

Glime, J.M. 2017. Bryophyte strategies, volume 1: physiological ecology. Chapters 4-10. Michigan Technological University, and the International Association of Bryologists. <http:// digitalcommons.mtu.edu/bryophyte-ecology1/>. Accessed 8 June 2017.

Grgurinovic C. 1994. Flora of Australia: volume 55, lichens-Lecanorales 2, Parmeliaceae. Australian Government Publishing Service, Canberra, Australian Capital Territory, Australia.

Hutsemekers, V., C. Dopagne, and A. Vanderpoorten. 2008. How far and how fast do bryophytes travel at the landscape scale? Diversity and Distributions 14: 483-492. doi: 10.1111/j.1472-4642.2007.00454.x

Hylander, K., and S. Johnson. 2010. In situ survival of forest bryophytes in small-scale refugia after an intense forest fire. Journal of Vegetation Science 21(6): 1099-1109. doi: 10.1111/j.1654-1103.2010.01220.x

Iglesias, N., V. Delgado, and A. Ederra. 2015. A comparison between the diaspore bank and above-ground bryoflora in the beech forests of Navarra (northern Spain). Cryptogamie, Bryologie 36(1): 19-40. doi: 10.7872/cryb.v36.iss1.2015.19

Jackson, T.A. 1971. Study of the ecology of pioneer lichens, mosses, and algae on recent Hawaiian lava flows. Pacific Science 25: 22-32.

Jarque, C., and A. Bera. 1987. A test for normality of observations and regression residuals. International Statistical Review 55(2): 163-172. doi: 10.2307/1403192

Johansson, V., T. Snäll, and T. Ranius. 2013. Estimates of connectivity reveal non-equilibrium epiphyte occurrence patterns almost 180 years after habitat decline. Oecologia 172(2): 607615. doi: 10.1007/s00442-012-2509-3

Kantvilas, G., and S.J. Jarman. 2012. Lichens and bryophytes in Tasmanian wet eucalypt forest: floristics, conservation and ecology. Phytotaxa 59(1): 1-31. doi: 10.11646/phytotaxa.59.1.1

Kantvilas, G., S.J. Jarman, and P.R. Minchin. 2015. Early impacts of disturbance on lichens, mosses and liverworts in Tasmania's wet eucalypt production forests. Australian Forestry 78: 92-107. doi: 10.1080/00049158.2015.1053025

Kumar, P., H.Y. Chen, S.C. Thomas, and C. Shahi. 2017. Effects of coarse woody debris on plant and lichen species composition in boreal forests. Journal of Vegetation Science 28: 389-400. doi: 10.1111/jvs. 12485

Laenen, B., A. Machac, S.R. Gradstein, B. Shaw, J. Patiño, A. Désamoré, B. Goffinet, C.J. Cox, J. Shaw, and A. Vanderpoorten. 2016. Geographical range in liverworts: does sex really matter? Journal of Biogeography 43: 627-635. doi: 10.1111/jbi.12661

Lewis, L.R., E. Behling, H. Gousse, E. Qian, C.S. Elphick, J.F. Lamarre, J. Bêty, J. Liebezeit, R. Rozzi, and B. Goffinet. 2014. First evidence of bryophyte diaspores in the plumage of transequatorial migrant birds. PeerJ 2: e424. doi: 10.7717/peerj.424

Löbel, S., T. Snäll, and H. Rydin. 2006. Metapopulation processes in epiphytes inferred from patterns of regional distribution and local abundance in fragmented forest landscapes. Journal of Ecology 94(4): 856-868. doi: 10.1111/j.1365-2745.2006.01114.x

Lönnell, N., B.G. Jonsson, and K. Hylander. 2014. Production of diaspores at the landscape level regulates local colonization: an experiment with a spore-dispersed moss. Ecography 37(6): 591-598. doi: 10.1111/j.1600-0587.2013.00530.x

Lumbsch, H.T., P.M. McCarthy, and W.M. Malcolm. 2001. Key to the genera of Australian lichens apothecial crusts. Flora of Australia Supplementary Series 11. Australian Biological Resources Study, Canberra, Australian Capital Territory, Australia. 
MathWorks. 2017. MATLAB jbtest. <https://au.mathworks.com/help/stats/jbtest.html>. Accessed 11 June 2017.

Mattiske, E.M., and J.J. Havel. 1998. Regional Forest Agreement vegetation complexes. Department of Conservation and Land Management, Como, Western Australia, Australia.

Mattiske, E.M., and J.J. Havel. 2000. Vegetation mapping in the south west of Western Australia. Department of Conservation and Land Management, Perth, Western Australia, Australia.

McCarthy, P.M. 2006. Flora of Australia, volume 51 (mosses 1). Australian Biological Resources Study, Canberra, Australian Capital Territory, Australia; CSIRO Publishing, Canberra, Australian Capital Territory, Australia.

McCarthy, P.M. 2009. Flora of Australia, volume 57, lichens 5. Australian Biological Resources Study, Canberra, Australian Capital Territory, Australia; CSIRO Publishing, Melbourne, Victoria, Australia.

McCarthy, P.M., and W.M. Malcolm. 2004. Key to the genera of Australian macrolichens. Flora of Australia supplementary series number 23. Australian Biological Resources Study, Canberra, Australian Capital Territory, Australia.

McCarthy, P.M., and K. Mallett. 2004. Flora of Australia, volume 56A, lichens 4. Australian Biological Resources Study, Canberra, Australian Capital Territory, Australia; CSIRO Publishing, Melbourne, Victoria, Australia.

McCaw, W.L., R.M. Robinson, and M.R. Williams. 2011. Integrated biodiversity monitoring for the jarrah (Eucalyptus marginata) forest in south-west Western Australia: the FORESTCHECK project. Australian Forestry 74(4): 240-253. doi: 10.1080/00049158.2011.10676369

Medina, N.G., B. Albertos, F. Lara, V. Mazimpaka, R. Garilleti, D. Draper, and J. Hortal. 2014. Species richness of epiphytic bryophytes: drivers across scales on the edge of the Mediterranean. Ecography 37(1): 80-93. doi: 10.1111/j.1600-0587.2013.00095.x

Mittelbach, G.G., and D.W. Schemske. 2015. Ecological and evolutionary perspectives on community assembly. Trends in Ecology \& Evolution 30(5): 241-247. doi: 10.1016/j. tree.2015.02.008

Nascimbene, J., H. Mayrhofer, M. Dainese, and P.O. Bilovitz. 2017. Assembly patterns of soil-dwelling lichens after glacier retreat in the European Alps. Journal of Biogeography 44: 1393-1404. doi: 10.1111/jbi.12970

Paquette, M., C. Boudreault, N. Fenton, D. Pothier, and Y. Bergeron. 2016. Bryophyte species assemblages in fire and clear-cut origin boreal forests. Forest Ecology and Management 359: 99-108. doi: 10.1016/j.foreco.2015.09.031

Parr, C.L., and A.N. Andersen. 2006. Patch mosaic burning for biodiversity conservation: a critique of the pyrodiversity paradigm. Conservation Biology 20(6): 1610-1619. doi: 10.1111/j.1523-1739.2006.00492.x

Pharo, E.J., D.A. Meagher, and D.B. Lindenmayer. 2013. Bryophyte persistence following major fire in Eucalypt forest of southern Australia. Forest Ecology and Management 296: 2432. doi: 10.1016/j.foreco.2013.01.018

Robinson, N.M., S.W. Leonard, E.G. Ritchie, M. Bassett, E.K. Chia, S. Buckingham, H. Gibb, A.F. Bennett, and M.F. Clarke. 2013. Review: refuges for fauna in fire-prone landscapes: their ecological function and importance. Journal of Applied Ecology 50(6): 1321-1329. doi: 10.1111/1365-2664.12153

Roxburgh, S.H., K. Shea, and J.B. Wilson. 2004. The intermediate disturbance hypothesis: patch dynamics and mechanisms of species coexistence. Ecology 85: 359-371. doi: 10.1890/ 03-0266 
Rudolphi, J. 2009. Ant-mediated dispersal of asexual moss propagules. The Bryologist 112(1): 73-79. doi: 10.1639/0007-2745-112.1.73

Ryömä, R., and S. Laaka-Lindberg. 2005. Bryophyte recolonization on burnt soil and logs. Scandinavian Journal of Forest Research 20(S6): 5-16. doi: 10.1080/14004080510043361

Scott, G.A.M. 1985. Southern Australian liverworts. Australian Government Publishing Service, Canberra, Australian Capital Territory, Australia.

Singh, G., F. Dal Grande, S. Werth, and C. Scheidegger. 2015. Long-term consequences of disturbances on reproductive strategies of the rare epiphytic lichen Lobaria pulmonaria: clonality a gift and a curse. FEMS Microbiology Ecology 91: 1-11. doi: 10.1093/femsec/fiu009

Smith, R.J., S.R. Abella, and L.R. Stark. 2014. Post-fire recovery of desert bryophyte communities: effects of fires and propagule soil banks. Journal of Vegetation Science 25(2): 447-456. doi: $10.1111 /$ jvs. 12094

Smith, R.J., and L.R. Stark. 2014. Habitat vs. dispersal constraints on bryophyte diversity in the Mojave Desert, USA. Journal of Arid Environments 102: 76-81. doi: 10.1016/j. jaridenv.2013.11.011

Stein, A., K. Gerstner, and H. Kreft. 2014. Environmental heterogeneity as a universal driver of species richness across taxa, biomes and spatial scales. Ecology letters 17(7): 866-880. doi: 10.1111/ele.12277

Turner, P.A.M, and E.J. Pharo. 2005. The influence of substrate type and forest age on bryophyte species distribution in Tasmanian mixed forest. The Bryologist 108: 67-85. doi: 10.1639/0007-2745(2005)108[67:IOSTAF]2.0.CO;2

Turner, P.A.M., J.B. Kirkpatrick, and E.J. Pharo. 2011. Dependence of bryophyte species on young, mature and old growth wet eucalypt forest. Biological Conservation 144: 2951-2957. doi: 10.1016/j.biocon.2011.08.016

Virtanen, R. 2014. Diaspore and shoot size as drivers of local, regional and global bryophyte distributions. Global Ecology and Biogeography 23(6): 610-619. doi: 10.1111/geb.12128

Werth, S., H.H. Wagner, F. Gugerli, R. Holderegger, D. Csencsics, J.M. Kalwij, and C. Scheidegger. 2006. Quantifying dispersal and establishment limitation in an epiphytic lichen. Ecology 87(8): 2037-2046. doi: 10.1890/0012-9658(2006)87[2037:QDAELI]2.0.CO;2

Wittkuhn, R., and T. Hamilton. 2010. Using fire history data to map temporal sequences of fire return intervals and seasons. Fire Ecology 6: 97-114. doi: 10.4996/fireecology.0602097

Zanatta, F., J. Patiño, F. Lebeau, M. Massinon, K. Hylander, M. de Haan, P. Ballings, J. Degreef, and A. Vanderpoorten. 2016. Measuring spore settling velocity for an improved assessment of dispersal rates in mosses. Annals of Botany 118(2): 197-206. doi: 10.1093/aob/mcw092

Zar, J.H. 1974. Biostatistical analysis. Prentice Hall, Upper Saddle River, New Jersey, USA.

Zona, S. 2013. Millipedes transport gemmae of Calymperes palisotii (Bryophyta: Calymperaceae). Nova Hedwigia 97(3-4): 477-483. doi: 10.1127/0029-5035/2013/0132 